\title{
PENGARUH PENGGUNAAN MEDIA PEMBELAJARAN BERBASIS KOMPUTER TERHADAP HASIL BELAJAR MENGGAMBAR TEKNIK DASAR PADA SISWA KELAS X PROGRAM KEAHLIAN TEKNIK GAMBAR BANGUNAN SMK NEGERI 2 MEDAN
}

\author{
Nancy S Baringbing ${ }^{1}$, Parlaungan Hutagaol ${ }^{2}$ \\ ${ }^{1}$ Alumni Program Studi Pendidikan Teknik Bangunan, Fakultas Teknik UNIMED \\ ${ }^{2}$ Dosen Pengajar Jurusan Pendidikan Teknik Bangunan, Fakultas Teknik UNIMED \\ (parlaunganhutagoal@gmail.com)
}

\begin{abstract}
ABSTRAK
Penelitian ini bertujuan untuk mengetahui pengaruh media pembelajaran berbasis komputer terhadap hasil belajar MTD siswa kelas X Jurusan Teknik Bangunan di SMK Negeri 2 Medan. Sampel penelitian ini adalah seluruh siswa kelas X Jurusan Teknik Bangunan di SMK Negeri 2 Medan yang diambil secara acak dengan undian sehingga didapat, Kelas X Bangunan Gambar (TBG 2 ) sebagai kelas Drill and Practice dengan jumlah siswa 31 orang dan Kelas X Bangunan Gambar (TBG3) sebagai kelas tutorial dengan jumlah siswa 37 orang. Jadi total subjek yang diteliti adalah sebanyak 68 orang. Sebelum penelitian ini dilakukan, instrumen penelitian terlebih dahulu di uji cobakan, dilanjutkan dengan uji validitas dan uji reliabilitas. Uji validitas butir tes digunakan rumus korelasi product moment. Uji reliabilitas tes digunakan rumus K-R20, instrumen tes hasil belajar MTD yang valid diperoleh 30 butir dari 38 butir tes yang di ujicobakan, dan koefisien reliabilitasnya sebesar 0.8960 . Dalam uji normalitas pre-test dan post-test pada kedua kelas diperoleh bahwa $F_{\text {hitung }}<\mathrm{F}_{\text {tabel, }}$, sehingga distribusi dinyatakan normal. Pada uji Homogenitas dilakukan uji kesamaan dua varians maka didapatkan hasil 1,06<1,865, sehingga dapat disimpulkan hasil belajar kedua kelas juga memiliki varians yang sama atau Homogen. Pada uji hipotesis dengan menggunakan uji $t$ diperoleh bahwa, setelah kelas drill and practice dikenai perlakuan dan setelah dikenai perlakuan dengan pembelajaran tutorial, nilai $t_{\text {hitung }}$ dikonsultasikan dengan $t_{\text {tabel }}$ pada $\mathrm{db}=66$ dan $\mathrm{a}=0,05$, diperoleh harga $\mathrm{t}_{\text {tabel }}=1,671$, berarti $t_{\text {hitung }}=4,43>t_{\text {tabel }}=1,671$, maka dinyatakan Ho ditolak dan Ha diterima bahwa pembelajaran berbasis komputer memberi pengaruh terhadap peningkatan hasil belajar MTD pada siswa kelas $\mathrm{X}$ Jurusan Teknik Bangunan di SMK Negeri 2 Medan.
\end{abstract}

Kata Kunci :Berbasis Komputer, Hasil Belajar, Teknik Bangunan

\begin{abstract}
This study aims to know the effect of computer-based learning media on learning outcomes of students of class X MTD Building Engineering Department at SMK Negeri 2 Medan. The sample was all students of class X Engineering Building at SMK Negeri 2 Medan drawn at random by the lottery so obtained, Class X Building Pictures (TBG2) as a class Drill and Practice with the number of students 31 and Class X Building Pictures (TBG3) as tutorial classes the number of students 37 people. So the total subjects studied were as many as 68 people. Prior to this research, the research instruments must first be tested, followed by validity and reliability testing. Test the validity of the test used product moment correlation formula. Test the reliability of the test used formula K-R20, achievement test valid MTD obtained 30 items of 38 points test in ujicobakan, and reliability coefficient of 0.8960. In a test of normality pre-test and post-test in the second grade obtained that Fhitung $<$ Ftabel, so the otherwise normal distribution. Homogeneity tests performed on two variances equality test results are obtained $1.06<1.865$, so it can be concluded both classroom learning outcomes also have the same
\end{abstract}


variance or Homogeneous. In the hypothesis test using $t$ test showed that, after class drill and practice subjected to treatment and after being treated with learning tutorial, tcount consulted with ttable on $d b=66$ and $a=0.05$, obtained price table $=1.671$, meaning $t=4.43>$ table $=1.671$, then declared Ho rejected and Ha accepted that computer-based learning influences the learning outcome MTD in class X Building Engineering Department at SMK Negeri 2 Medan.

Keywords: Computer Based, Learning Outcomes, Engineering Building

\section{Pendahuluan}

Spektrum Sekolah Menengah Kejuruan (2008), SMK memiliki tujuan untuk : 1) menyiapkan peserta didik agar menjadi manusia produktif, mampu bekerja mandiri, mengisi lowongan pekerjaan yang ada di dunia usaha dan dunia industri sebagai tenaga kerja tingkat menengah sesuai dengan kompetisi dalam program keahlian yang dipilihnya, 2) menyiapkan peserta didik agar mampu memilih karir, ulet dan gigih dalam berkompetensi, beradaptasi di lingkungan kerja, dan mengembangkan sikap profesional dalam bidang keahlian yang diminatinya, 3) membekali peserta didik dengan ilmu pengetahuan, teknologi dan seni, agar mampu mengembangkan diri di kemudian hari baik secara mandiri maupun melalui jenjang pendidikan yang lebih tinggi, 4) membekali peserta didik dengan kompetensi - kompetensi yang sesuai dengan program keahlian yang dipilihnya.

SMK Negeri 2 Medan merupakan salah satu lembaga pendidikan formal yang memberi bekal pengetahuan, teknologi, keterampilan, sikap mandiri, disiplin, serta etos kerja yang terampil dan kreatif sehingga kelak menjadi tenaga kerja yang memiliki pengetahuan dan keterampilan tingkat menengah yang sesuai dengan bidangnya.

Sesuai dengan tujuan dari SMK diatas, maka lulusan SMK Program Keahlian Teknik Gambar Bangunan diharapkan dapat menguasai gambar teknik baik secara teori maupun prakteknya agar dapat bersaing dalam penerapan ilmu yang diperoleh sesuai dengan bidangnya dilapangan kerja.

Pada mata diklat Menggambar Teknik Dasar siswa harus dapat mengetahui jenis jenis peralatan yang dipakai untuk menggambar dan cara - cara dasar dalam menggambar. Pada kenyataannya, dari hasil pengamatan yang saya lakukan di SMK Negeri 2 Medan didapatkan bahwa nilai mata pelajaran MTD belum sesuai dengan kriteria nilai ideal ketuntasan belajar yaitu $\geq 75$. Pada tahun 2012/2013 sebanyak 27,8\% belum mencapai standar ketuntasan nilai, sedangkan pada tahun 2013/2014 sebanyak 22.2\% belum mencapai standar ketuntasan nilai. Berikut daftar nilai siswa hasil belajar mata pelajaran Menggambar Teknik Dasar di SMK Negeri 2 Medan.

Tabel 1. Persentase Nilai Menggambar Teknik Dasar Ujian Harian di SMK Negeri 2 Medan

\begin{tabular}{|c|c|c|c|c|}
\hline TA & $\begin{array}{c}\text { Interval } \\
\text { Kelas }\end{array}$ & $\begin{array}{l}\text { JLH } \\
\text { Sis } \\
\text { wa }\end{array}$ & $\%$ tase & Ket \\
\hline \multirow{4}{*}{$\begin{array}{r}2012 / \\
2013\end{array}$} & $\leq 6.9$ & 10 & $27.8 \%$ & $\begin{array}{l}\text { Belum } \\
\text { tuntas }\end{array}$ \\
\hline & $7-7.90$ & 21 & $58.3 \%$ & \multirow{3}{*}{$\begin{array}{l}\text { Tuntas } \\
\text { Tuntas } \\
\text { Tuntas }\end{array}$} \\
\hline & $8-8.9$ & 4 & $11.1 \%$ & \\
\hline & $9-10$ & 1 & $2.8 \%$ & \\
\hline \multirow[t]{3}{*}{$\begin{array}{r}2013 / \\
2014\end{array}$} & $\leq 6.9$ & 8 & $22.2 \%$ & $\begin{array}{l}\text { Belum } \\
\text { tuntas }\end{array}$ \\
\hline & $\begin{array}{c}7-7.90 \\
8-8.9\end{array}$ & $\begin{array}{c}18 \\
8\end{array}$ & $\begin{array}{c}50 \% \\
22.2 \%\end{array}$ & \multirow{2}{*}{$\begin{array}{l}\text { Tuntas } \\
\text { Tuntas } \\
\text { Tuntas }\end{array}$} \\
\hline & $9-10$ & 2 & $5.6 \%$ & \\
\hline
\end{tabular}

Hal ini disebabkan banyaknya guru yang mengajar secara monoton yaitu hanya menggunakan satu metode pembelajaran saja. Misalnya metode konvensional. Selain itu terkadang guru tidak selalu tepat menggunakan metode pembelajaran. Sehingga, tanpa disadari ternyata metode tersebut sering menjadikan siswa enggan dan jenuh dalam menerima materi pelajaran sehingga tujuan yang ditetapkan tidak tercapai secara optimal.

Oleh karaena itu penelitian ini dilakukan adalah untuk meningkatkan hasil belajar yang diperoleh siswa melalui kegiatan belajar mengajar, seperti yang dikemukakan oleh Suryabrata dalam Siagian (2009:3) bahwa: hasil belajar dipengaruhi oleh dua faktor, yaitu faktor internal dan faktor eksternal. Faktor internal (faktor yang berasal dari dalam diri 


\section{Pengaruh Penggunaan Media Pembelajaran Berbasis Komputer Terhadap Hasil Belajar Menggunakan Teknik Dasar Pada Siswa Kelas X Program Keahlian Teknik Gambar Bangunan SMK Negeri 2 Medan}

siswa), meliputi: minat, bakat, kreativitas, motivasi, dan IQ, sedangkan faktor eksternal (faktor yang berasal dari luar siswa), meliputi: sarana dan prasarana, lingkungan, pendidikan, buku - buku, media, mempelajari, serta penguasaan perkembangan teknologi informasi yang dapat menunjang hasil belajar, metode belajar dan sebagainya.

Perbedaannya dengan pembelajaran konvensional adalah siswa diharapkan dapat lebih mengenal dan mengetahui jenis dan penggunaan alat-alat gambar dalam pembelajaran di kelas, sehingga siswa dapat mengaplikasikan alat-alat gambar tersebut ke dalam media gambar sesuai fungsinya.

Salah satu metode pembelajaran yang dapat membantu siswa dalam mata diklat menggambar teknik dasar adalah Media Pembelajaran Berbasis Komputer. Lebih lanjut dinyatakan bahwa dalam menggunakan media ini peran guru adalah menyajikan materi pelajaran, memilih pokok bahasan yang sesuai dengan media berbasis komputer ini, serta menentukan latihan yang sesuai dengan topik yang telah dipelajari agar siswa memilki ketangkasan atau keterampilan yang lebih tinggi dari apa yang telah dipelajari.

\section{Kajian Teori}

2.1 Hakikat Hasil Belajar Menggambar Teknik

Dasar

"Gambar teknik merupakan suatu sarana terpenting untuk melukiskan daya cipta lewat penggunaan garis. Purwanto (2006:3) “Gambar teknik adalah gambar yang dibuat dengan menggunakan cara-cara, ketentuan-ketentuan, aturan-aturan yang telah disepakati bersama oleh ahli-ahli teknik. Sebagai suatu alat komunikasi, gambar teknik mengandung maksud tertentu, perintah-perintah, atau informasi dari pembuat gambar (perencana) untuk di sampaikan kepada pelaksana atau pekerja di lapangan dalam bentuk gambar kerja yang dilengkapi dengan keterangan-keterangan berupa kode-kode, simbol yang mempunyai satu arti, satu maksud, dan satu tujuan".

Menggambar teknik dasar merupakan salah satu mata diklat yang harus dikuasai oleh siswa SMK Jurusan Teknik Bangunan. Di mana pada mata diklat inilah dipelajari dasar-dasar dari menggambar teknik yang meliputi pokok bahasan menggambar kurva hiperbola, menggambar benda geometri tiga dimensi, menggambar isometri silinder serta menggambar proyeksi bangunan.

Sedangkan menurut Hamalik (2008:49) fungsi media pembelajaran yaitu: a) Untuk mewujudkan situasi pembelajaran yang efektif, b) Penggunaan media merupakan bagian integral dalam system pembelajaran, c) Media pembelajaran penting dalam rangka mencapai tujuan pembelajaran, d) Penggunaan media dalam pembelajaran, e) Penggunaan media dalam pembelajaran dimaksudkan untuk mempertinggi mutu pendidikan.

\subsection{Media Pembelajaran Berbasis Komputer}

Pembelajaran berbasis komputer (Computer Based Instruction) pada pembelajaran memiliki manfaat yang signifikan pada proses pembelajaran.

\subsubsection{Tipe Pembelajaran Berbasis Komputer}

Sesuai dengan kajian teori dalam Computer Based Instruction (CBI) yakni empat tipe pembelajaran Media Berbasis Komputer yaitu : (1) Tipe Pembelajaran Drill and Practice (2) Tipe Pembelajaran Tutorial (3) Tipe Pembelajaran Permainan/Games, dan, (4) Tipe Pembelajaran Simulasi. Hanya 2 (dua) tipe yang akan dibahas lebih rinci.

\section{a. Metode Pembelajaran Drill and Practice}

"Metode Drill and Practice ialah suatu teknik yang dapat diartikan sebagai suatu cara mengajar dimana siswa melaksanakan kegiatan-kegiatan latihan, agar siswa memiliki ketangkasan atau keterampilan yang lebih tinggi dari apa yang telah dipelajari" (N. K. Roestiyah, 2008). Sedangkan menurut Sagala (2009) "metode latihan (drill) atau metode training merupakan suatu cara mengajar yang baik untuk menanamkan kebiasaan-kebiasaan tertentu. Juga sebagai sarana untuk memperoleh suatu ketangkasan, ketepatan, kesempatan dan keterampilan".

Berdasarkan uraian di atas dapat disimpulkan bahwa metode Drill and Practice merupakan suatu cara mengajar/ teknik yang baik untuk memperoleh 
suatu ketangkasan dan keterampilan dari apa yang telah dipelajari.

Hal-hal tersebut diatas dapat berhasil apabila siswa juga mengerti konteks keseluruhan dari metode drill bagi dirinya. Pakar pendidikan, Hover mengatakan bahwa: "(1) pembelajaran itu sebenarnya efektif bagi masingmasing siswa, (2) pembelajaran pada dasarnya adalah proses mengatasi masalah sehingga siswa ditegaskan agar dapat mencari hubungan akan sesuatu hal dengan Drill \& Practice sehingga ia dapat mencapai standar minimumnya sendiri untuk objek yang ia teliti dan guru hanya berperan sebagai fasilita or"

\section{b. Metode Pembelajaran Tutorial}

Tutorial adalah bimbingan pembelajaran dalam bentuk pemeberian arahan, bantuan, petunjuk, dan motivasi agar para siswa belajar secara efisien dan efektif.

Tahapan atau langkah-langkah pembelajaran berbasis komputer model tutorial adalah sebagai berikut:

1) Penyajian informasi (presentation of information), yaitu berupa materi pelajaran yang akan dipelajari siswa

2) Pertanyaan dan respon (Qustion of Responses), yaitu berupa soal-soal latihan yang harus dikerjakan siswa

3) Penilaian respon (Judging of responses), yaitu komputer akan memberikan respon terhadap kinerja dan jawaban siswa

4) Pemberian balikan respon (providing feedback abaout responses), yaitu setelah selesai, program akan memberikan balikan. Apakah telah suskes atau berhasil atau harus mengulang.

5) Pengulangan (remediation)

6) Segmen pengaturan pelajaran (Sequencing lesson segment).

\section{c. Tipe Pembelajaran Permainan/Games}

Pembelajaran Permainan atau Instructional games merupakan salah satu bentuk metode dalam pembelajaran berbasis komputer. Tujuannya adalah untuk menyediakan pengalaman belajar yang memberikan fasilitas belajar untuk menambah kemampuan siswa melalui bentuk permainan yang mendidik. Instructional games tidak perlu menirukan realita namun dapat memiliki karakter yang menyediakan tantangan yang menyenangkan bagi siswa.

Tahapan yang harus ditempuh dalam pembuatan instructional games sebagai model pembelajaran yaitu: 1) tujuan, 2) Aturan, 3) Kompetisi, 4) Tantangan, 5) Khayalan, 6) Keamanan, 7) Hiburan

Tujuan kegiatan belajar melalui permaianan semakin popular dalam pendidikan sebab guru mulai menyadari potensi yang dimilikinya untuk memotivasi siswa dalam belajar.

\section{d. Tipe pembelajaran model Simulasi}

Menurut Arsyad (2002:161) Model simulasi pada"Program simulasi dengan bantuan komputer mencoba untuk menyamai proses dinamis yang terjadi didunia nyata.

Model simulasi terbagi ke dalam 4 kategori: fisik, situasim prosedur, dan proses. Secara umum tahapan materi model simulasi adalah sebagai berikut: a) pengenalan, 2) penyajian, 3) pertanyaan dan respon jawaban, 4) penilaian respon, 5) pemberian feedback tentang respon, 6) pembetulan, 7) segmen pengaturan pengajaran, 8) penutup.

\section{Metodologi Penelitian}

Penelitian ini dilaksanakan di SMK Negeri 2 Medan Jl. STM No.12 A pada. Penelitian ini dilakukan di bulan Februari pada tahun 2015. Sampel penelitian ini adalah seluruh siswa kelas X Jurusan Teknik Bangunan di SMK Negeri 2 Medan yang diambil secara acak dengan undian sehingga didapat:

a. Kelas $X$ Bangunan Gambar $\left(\mathrm{TBG}^{2}\right)$ : kelompok A1: Sebagai kelas media pembelajaran berbasis komputer tipe Drill and Practice berjumlah 31 orang

b. Kelas $\mathrm{X}$ bangunan Gambar $\left(\mathrm{TBG}^{3}\right)$ : Kelompok A2: Sebagai kelas media pembelajaran berbasis komputer tipe Tutorial berjumlah 37 orang serta variabel penelitian yaitu:

Variabel bebas terdiri dari dua kelompok yaitu kelompok pertama yang dikenai 


\section{Pengaruh Penggunaan Media Pembelajaran Berbasis Komputer Terhadap Hasil Belajar Menggunakan Teknik Dasar Pada Siswa Kelas X Program Keahlian Teknik Gambar Bangunan SMK Negeri 2 Medan}

perlakuan pemberian pelajaran dengan media pembelajaran Berbasis Komputer tipe Drill and Practice $\left(\mathrm{X}_{1}\right)$ dan kelompok kedua media pembelajaran Berbasis Komputer tipe Tutorial $\left(\mathrm{X}_{2}\right)$.Variabel terikat $(\mathrm{Y})$ penelitian ini adalah hasil belajar menggambar teknik dasar siswa.

\subsection{Desain Penelitian}

Penelitian ini menggunakan kelompok A1 sebagai Media pembelajaran berbasis komputer tipe Drill and Practice dan kelompok A2 sebagai Media Pembelajaran berbasis komputer tipe Tutorial. Penelitian ini dilakukan untuk mengetahui apakah metode pembelajaran Berbasis Komputer memberi pengaruh yang berbeda terhadap hasil belajar menggambar teknik dasar. Rancangan penelitian dimaksud adalah seperti pada tabel 2 dibawah ini.

Tabel 2. Desain Test Awal dan Test Akhir

\begin{tabular}{clccc}
\hline $\begin{array}{l}\text { Kelom } \\
\text { Pok }\end{array}$ & Group & $\begin{array}{l}\text { Tes } \\
\text { Awal }\end{array}$ & $\begin{array}{l}\text { Per } \\
\text { lakuan }\end{array}$ & $\begin{array}{l}\text { Tes } \\
\text { Akhir }\end{array}$ \\
\hline A1 & $\begin{array}{l}\text { Berbasis } \\
\text { Komputer tipe }\end{array}$ & $\mathrm{T}_{1}$ & $\mathrm{X}_{1}$ & $\mathrm{~T}_{2}$ \\
& $\begin{array}{l}\text { Drill and } \\
\text { Practice }\end{array}$ & & & \\
A2 & $\begin{array}{l}\text { Berbasis } \\
\text { komputer tipe } \\
\text { tutorial }\end{array}$ & $\mathrm{T}_{1}$ & $\mathrm{X}_{2}$ & $\mathrm{~T}_{2}$ \\
\hline
\end{tabular}

Keterangan:

$\mathrm{A}_{1}$ : Kelompok Media Pembelajran Berbasis Komputer tipe Drill and Practice

$\mathrm{A}_{2}$ : Kelompok Kelompok Media Pembelajran Berbasis Komputer Tutorial

$\mathrm{X}_{1}$ : Media pembelajaran Berbasis Komputer tipe Drill and Practice

$\mathrm{X}_{2}$ : Media Pembeljaran Berbdasis Komputer tipe Tutorial

$\mathrm{T}_{1}$ : Hasil belajar Menggambar Teknik Dasar sebelum perlakuan

$\mathrm{T}_{2}$ : Hasil belajar Menggambar Teknik Dasar sesudah perlakuan.

\subsection{Kontrol terhadap Eksperimen}

Untuk mendapatkan suatu keyakinan bahwa data penelitian yang akan diperoleh adalah baik, maka diperlukan pengontrolan kesahihan eksternal (eksternal validity) dan kesahian internal (internal validity) terhadap teknik pengumpul data. Pengontrolan tersebut dilakukan terhadap:

\subsubsection{Kesahihan eksternal (Eksternal validity)}

a) Kesahihan populasi

Kesahihan ini merupakan pengontrolan terhadap populasi dari subjek penelitian. Kesahihan pupulasi ini dikontrol dengan cara:

1) Mengambil subjek penelitian siswa kelas $\mathrm{X}$ jurusan Teknik Bangunan di SMK Negeri 2 Medan.

2) Mengambil jumlah subjek penelitian dengan cara teknik sampel bertujuan (purposive sampling)

\section{b) Kesahihan ekologi}

Pengontrolan kesahihan ekologi dimaksud untuk menghindari pengaruh reaktif dari prosedur penelitian, yaitu pengontrolan terhadap hal-hal yang berhubungan dan penggeneralisasian hasil eksperimen terhadap kondisi lingkungan. Kesahihan ekologi dikontrol dengan cara:

1) Tidak memberitahu kepada siswa bahwa mereka sedang menjadi sampel penelitian.

2) Membuat suasana kelas sama dengan keadaan sehari-hari dengan :

- Tidak merubah jadwal mata pelajaran

- Memberikan perlakukan yang sama bagi semua siswa dalam kelas.

3) Guru yang menjalankan perlakuan adalah guru yang memberikan mata diklat Menggambar Teknik Dasar, dengan demikian siswa tidak mengalami perubahan guru.

4) Memberikan perlakuan dalam situasi yang sesuai dengan keadaan seharihari. Dengan demikin siswa yang dijadikan subjek penelitian tetap berada dalam kelasnya masing-masing.

\subsubsection{Kesahihan Internal (internal validity)}

Agar hasil penelitian yang diperoleh adalah benar-benar merupakan akibat 
perlakuan yang diberikan kepada kelas eksperimen maka sangat diperlukan pengontrolah kesahihan internal, yaitu:

a) Pengaruh historis

Pengaruh historis dikontrol dengan cara mencegah timbulnya kejadiankejadian khusus yang bukan karena perlakuan yang diberikan.

b) Pengaruh kematangan dan kejenuhan

Pengaruh kematangan dan kejenuhan dikontrol dengan cara mengusahakan pelaksanaan perlakuan dalam waktu yang tidak begitu lama.

c) Pengaruh tes awal

Pengaruh tes awal dihindari dengan jalan mengawasi pelaksanaan tes awal dengan ketat dan mengumpulkan kembali lembaran soal setelah tes awal selesai, sehingga tidak ada lembaran soal yang hilang. Jarak antara tes awal dan tes akhir juga dilakukan dalam waktu tidak berdekatan. Hal ini untuk menghindari asumsi siswa masih jelas mengingat materi soal yang diberikan.

d) Pengaruh instrumen pengukuran Pengaruh instrumen pengukuran dikontrol dengan tidak mengadakan perubahan-perubahan pada bentuk tes yang dipakai setelah di uji coba.

e) Pengaruh kehilangan peserta eksperimen

Pengaruh kehilangan peserta eksperimen dikontrol dengan cara mengadakan daftar hadir siswa.

f) Kontaminasi kelas eksperimen

Kontaminasi kelas eksperimen dikontrol dengan cara tidak memberitahukan mengenai adanya penelitian kepada siswa.

Penelitian ini akan mengikuti kalender pendidik

\subsection{Instrumen Penelitian}

Instrumen penelitian yang digunakan untuk mengumpulkan data hasil belajar siswa adalah tes hasil belajar siswa pada mata diklat Menggambar Teknik Dasar. Tes ini berbentuk pilihan ganda sebanyak 30 soal dengan empat option pilihan. Dalam penyusunan tes ini digunakan dari kumpulan soal-soal dari materi pelajaran. Kriteria penilaian adalah memberikan skor 1 untuk setiap soal yang dijawab benar dan skor 0 untuk setiap soal yang dijawab salah.

\subsection{Uji Coba Instrumen Penelitian}

Uji coba instrumen bertujuan untuk mendapatkan alat ukur yang benar-benar sahih dan terhandal sebelum instrumen tersebut digunakan untuk menjaring ubahan yang sebenarnya. Penggunaan instrumen yang sahih dan handal dimaksud untuk mendapatkan datadata dari masing-masing ubahan yang hasilnya akurat dan kesimpulan yang diperoleh dapat dipertanggungjawabkan secara ilmiah dan sesuai dengan kenyataan.Untuk uji coba instrument ini dilaksanakan pada tanggal 29 Januari 2015 di SMK N 2 Medan pada kelas XI Program Keahlian Teknik Gambar Bangunan berjumlah 30 orang. Soal yang diberikan sebanyak 38 butir.

\subsubsection{Validitas Tes.}

Validitas tes menunjukkan sejauh mana alat pengukur itu mengukur apa yang akan diukur. Validitas butir adalah butir tes yang dapat menjalankan fungsi pengukurannya dengan baik, hal ini dapat diketahui dari seberapa besar peran yang diberikan oleh butir soal tes tersebut dalam mencapai keseluruhan skor seluruh tes dengan jalan mengkorelasikan antara skor yang diperoleh dari butir tersebut dengan skor totalnya dengan menggunakan korelasi Point Biserial.

$$
\mathrm{r}_{\mathrm{pbi}}=\frac{M_{p}-M_{t}}{S_{t}} \sqrt{\frac{p}{q}} \text { (Arikunto, 2006) }
$$

Keterangan :

$\mathrm{r}_{\mathrm{pbi}}=$ Koefisien korelasi biserial

$\mathrm{Mp}=$ Rerata skor subjek yang menjawab betul bagi item yang dicari validitasnya.

Mt $=$ Rerata skor total

St $=$ Standar deviasi dari skor total

$\mathrm{p}=$ proporsi siswa yang menjawab benar.

$\mathrm{q}$ = proporsi siswa yang menjawab salah $(\mathrm{q}=$ $1-p)$

Kemudian harga $\gamma_{\mathrm{pbi}}$ dikonsultasikan dengan harga $r_{\text {tabel }}$ pada taraf signifikan $5 \%$. Apabila $\gamma_{p b i}>r_{\text {tabel }}$ maka butir tes tersebut valid dan begitu juga sebaliknya. Hasil validitas untuk soal nomor 1 adalah valid dimana $\mathrm{r}_{\text {hitung }}$ sebesar 0,512 dikonsultasikan 


\section{Pengaruh Penggunaan Media Pembelajaran Berbasis Komputer Terhadap Hasil Belajar Menggunakan Teknik Dasar Pada Siswa Kelas X Program Keahlian Teknik Gambar Bangunan SMK Negeri 2 Medan}

dengan $\mathrm{r}_{\text {tabel }}$ pada taraf signifikan $5 \%$ untuk $\mathrm{N}=30$ diperoleh $\mathrm{r}_{\text {tabel }}$ 0,361. Sehingga diketahui bahwa soal nomor 1 adalah valid. Hasil ujian validitas dari 38 butir soal yang valid adalah 30 soal, maka soal yang dipergunakan pada tes hasil belajar adalah 30 soal.

\subsubsection{Reliabilitas Tes}

"Reliabilitas menunjukkan pada satu pengertian bahwa sesuatu instrumen cukup dapat dipercaya untuk digunakan sebagai alat pengumpul data karena instrumen tersebut sudah baik" (Arikunto, 2006). Instrumen yang dapat dipercaya/ reliabel akan menghasilkan data yang dapat dipercaya juga. Perhitungan reliabilitas tes dilakukan dengan menggunakan rumus Kudder-Richardson (KR) 20 (Arikunto, 2006).

$$
r_{11}=\left[\frac{n}{n-1}\right]\left[\frac{S^{2}-\sum p q}{S^{2}}\right]
$$

Keterangan :

$\mathrm{r}_{11}=$ reliabilitas instumen

$\mathrm{n}$ = banyaknya butir soal

$\mathrm{S}=$ variants total

$\mathrm{P}=$ proporsi siswa yang menjawab benar

$(p=$ banyaknya siswa yang menjawab benar / jumlah seluruh siswa)

$\mathrm{q}$ = proporsi siswa yang menjawab salah

$$
(\mathrm{q}=1-\mathrm{p})
$$

Untuk menafsirkan arti dari suatu koefisien reliabilitas dapat digunakan acuan/ indeks korelasi yang diberikan Arikunto, sebagai berikut :

Antara 0,80 sampai dengan 1,00 :

Reliabilitas sangat tinggi

Antara 0,60 sampai dengan 0,80 :

Reliabilitas tinggi

Antara 0,40 sampai dengan 0,60 :

Reliabilitas cukup

Antara 0,20 sampai dengan 0,40

Reliabilitas rendah

Antara 0,00 sampai dengan 0,20 :

Reliabilitas sangat rendah. Setelah dilakukan pengujian reliabilitas tes seperti pada (lampiran 9) maka didapat nilai reliabilitasnya sebesar 0,8960. Maka dapat disimpulkan reliabilitasnya sangat tinggi.

\subsubsection{Indeks Kesukaran Tes}

Indeks kesukaran tes ditentukan dengan menggunakan rumus yang dikemukakan (Arikunto, 2006) yaitu:

$$
P=\frac{B}{J S}
$$

Keterangan :

$\mathrm{P}=$ Indeks kesukaran tes

$\mathrm{B}=$ Banyak subyek yang menjawab benar JS = Jumlah seluruh siswa peserta tes.

Harga indeks kesukaran soal adalah sebagai berikut :

$0,00-0,30=$ soal kategori sukar

$0,31-0,70=$ soal kategori sedang

$0,71-1,00=$ soal ketegori mudah

Setelah dilakukan pengujian indeks kesukaran tes pada (lampiran 8) maka didapat ada 15 butir soal yang dikategorikan mudah, 22 butir soal yang dikategorikan sedang dan 1 butir soal yang dikategorikan sulit. Pada perhitungan indeks kesukaran soal nomor 1 didapat $\mathrm{P}=0,70$ dengan indeks kesukaran Mudah.

\subsubsection{Daya Pembeda}

Menurut Arikunto (2006) daya pembeda soal adalah kemampuan suatu soal untuk membedakan antara siswa yang pandai (berkemampuan tinggi) dengan siswa yang bodoh (berkemampuan rendah). Untuk mengetahui daya pembeda soal dihitung dengan rumus daya pembeda sebagai berikut:

$$
D=\frac{B A}{J A}-\frac{B B}{J B}
$$

Keterangan:

$\mathrm{D}$ = Daya beda soal

$\mathrm{BA}=$ Banyaknya peserta kelompok atas yang menjawab dengan benar

$\mathrm{BB}=$ Banyaknya peserta kelompok atas yang menjawab dengan benar

$\mathrm{JA}=$ Banyaknya Kelompok Atas

$\mathrm{JB}=$ Banyaknya kelompok Bawah

Adapun klasifikasi indeks daya pembeda soal menurut Arikunto (2006) adalah:

$\mathrm{D}=0,00$ sampai 0,20 butir soal jelek

$\mathrm{D}=0,21$ sampai 0,40 butir soal cukup

$\mathrm{D}=0,41$ sampai 0,70 butir soal baik 
$\mathrm{D}=0,71$ sampai 1,00 butir soal baik sekali

$\mathrm{D}$ = negatif, butir soal tidak baik

Pada perhitungan daya beda soal nomor

1 di dapat $D=13 / 15-8 / 15=0,33$

dengan status daya beda Cukup. 5 butir soal tes dikategorikan cukup, 24 butir soal tes dikategorikan baik, dan 8 butir soal tes dikategorikan jelek dan 1 dikategorikan sangat baik.

\subsection{Teknik Analisis Data}

\subsubsection{Deskripsi Data Penelitian}

Dalam pendeskripsian data, adapun langkah-langkah yang ditempuh adalah sebagai berikut:

\section{a. Menghitung rata-rata (Mean) dengan} rumus :

$$
\bar{X}=\frac{\sum X i}{N}(\text { Sudjana, 2005). }
$$

Dimana :

$$
\begin{aligned}
\bar{X} & =\text { Mean } \\
\mathrm{X} & =\text { Jumlah skor } \\
\mathrm{N} & =\text { Banyak data }
\end{aligned}
$$

b. Standard deviasi dihitung dengan rumus:

$\mathrm{S}=\sqrt{\frac{N \Sigma X^{2}-(\Sigma X)^{2}}{N(N-1)}}($ Arikunto, 2006)

\subsubsection{Uji Persyaratan Analisis}

Sebelum dilakukan uji hipotesis, maka data variabel penelitian harus memenuhi persyaratan normalitas dan homogenitas.

\subsubsection{Uji Normalitas}

Uji normalitas data digunakan uji liliefors sebagai berikut:

a. Data X1, X2, .........Xn dijadikan bilangan baku Z1, Z2, sampai Zn, dengan menggunakan rumus :

$$
\mathrm{Z}_{1}=\frac{X i-\bar{X}}{S}(\text { Sudjana,2005) (7) }
$$

b. Menghitung peluang

$$
\mathrm{F}(\mathrm{Zi})=\mathrm{P}(\mathrm{Z} \leq \mathrm{Zi})
$$

c. Selanjutnya menghitung proporsi S(zi) dengan rumus (Sudjana, 2005).:

$$
\mathrm{S}=\frac{\text { banyaknyaZ } Z_{1}, Z_{2, \ldots . . . Z n},<z_{1}}{N}
$$

d. Menghitung selisih F(Zi) - S(Zi) kemudian menentukan harga mutlak.

e. Mengambil harga Lo yaitu harga yang paling besar diantara harga mutlak, untuk menerima dan menolak hipotesis dibandingkan Lhitung dengan nilai kritis L yang diambil dari daftar nilai krisis uji liliefors dengan taraf signifikan $5 \%$.

f. Kriteria pengujiannya adalah: Jika $\mathrm{L}$ hitung $<\mathrm{L}_{\text {tabel }}$ maka sampel berdistribusi normal

\subsubsection{Uji Homogenitas}

Oleh karena itu, perlu dilakukan pengujian mengenai kesamaan dua varians atau lebih. Populasi-populasi dengan varians yang sama besar dinamakan varians yang homogen. Sedangkan populasi-populasi dengan varians yang tidak sama besar dinamakan populasi dengan varians yang heterogen. Untuk menguji homogenitas data digunakan uji $f$ (Sudjana, 2005). Untuk mengitung homogenitas digunakan rumus:

$$
F=\frac{\text { VariansTerbesar }}{\text { VariansTerkecil }}
$$

Kriteria pengujian adalah jika $\mathrm{F}$ hitung lebih kecil dari $\mathrm{F}$ tabel pada taraf signifikan 5\% maka data hasil penelitian adalah homogen.

\subsubsection{Pengujian Hipotesis}

"Hipotesis adalah suatu jawaban yang bersifat sementara terhadap masalah penelitian" (Arikunto, 2006). Untuk pengujian hipotesis penelitian ini dilakukan dengan menggunakan rumus uji-t (Sudjana, 2005).

$$
\mathrm{t}_{\text {hitung }}=\frac{\bar{X}_{1}-\bar{X}_{2}}{S \cdot \sqrt{\frac{1}{n_{1}}+\frac{1}{n_{2}}}}
$$

Dengan :

$$
S=\sqrt{\frac{\left(n_{1}-1\right) S_{1}^{2}+\left(n_{2}-1\right) S_{2}^{2}}{n_{1}+n_{2}-2}}
$$

Keterangan :

$\bar{X}_{1}=$ Nilai rata-rata kelompok yang diajarkan dengan menggunakan media 


\section{Pengaruh Penggunaan Media Pembelajaran Berbasis Komputer Terhadap Hasil Belajar Menggunakan Teknik Dasar Pada Siswa Kelas X Program Keahlian Teknik Gambar Bangunan SMK Negeri 2 Medan}

pembelajaran berbasis komputer tipe Drill and Practice

$\bar{X}_{2} \quad=$ Nilai rata-rata kelompok yang diajarkan dengan menggunakan media pembelajaran berbasis komputer tipe tutorial

$\mathrm{n}_{1}=$ Jumlah sampel kelompok yang diajar dengan menggunakan media pembelajaran berbasis komputer tipe Drill and Practice

$\mathrm{n}_{2}=$ Jumlah sampel kelompok yang diajarkan menggunakan media pembelajaran berbasis komputer tipe tutorial

$\mathrm{S}_{1}=$ Varians kelompok yang diajarkan dengan menggunakan media pembelajaran berbasis komputer tipe Drill and Practice

$\mathrm{S}_{2}=$ Varians kelompok yang diajarkan dengan menggunakan media pembelajaran komputer berbasis komputer tipe tutorial

$S^{2}=$ Varians Total

Setelah $t_{\text {Hitung }}$ diperoleh maka dikonsultasikan dengan nilai $\mathrm{t}_{\text {Tabel }}$ pada taraf a $=0,05$ dengan $\mathrm{dk}=\left(\mathrm{n}_{1}+\mathrm{n}_{2}-2\right)$ dan peluang $(1-$ $1 / 2 \alpha$ ) yang diperoleh dari daftar distribusi $t$ dengan statistik daerah penerimaan $\mathrm{H}_{\mathrm{o}}$ yaitu:

$-t_{(1-1 / 2 \alpha)} \leq \mathrm{t} \leq t_{(1-1 / 2 \alpha)}$

\subsubsection{Hipotesis Statistik}

Sesuai dengan hipotesis penelitian yang telah diungkapkan, maka hipotesis statistiknya dapat dirumuskan sebagai berikut:

$$
\text { Ha } \quad: \mu \mathrm{A}_{1} \geq \mu \mathrm{A}_{2}
$$

Dengan kalimat dapat dituliskan:

Ho : Rata-rata hasil belajar siswa pada pokok bahasan Mengidentifikasi peralatan dan media gambar teknik tidak lebih baik/ tinggi dengan media pembelajaran Drill and Practice daripada media pembelajaran Tutorial di kelas X Jurusan Teknik Bangunan SMK Negeri 2 Medan.

Ha: Rata-rata hasil belajar siswa pada pokok bahasan Mengidentifikasi peralatan dan media gambar teknik bangunan lebih baik/ tinggi dengan media pembelajaran Drill and Practice daripada media pembelajaran Tutorial di kelas $X$ Jurusan Teknik Bangunan SMK Negeri 2 Medan.
4. Hasil Penelitian

4.1 Hasil Belajar Siswa Siswa yang diajar dengan Media Pembelajaran Tipe Drill dan Practice

Berdasarkan tes hasil belajar yang diberikan setelah proses pemberian perlakuan, skor tertinggi pada siswa yang diajar dengan menggunakan Media pembelajaran Tipe Drill and Practice memiliki skor rata-rata $(\mathrm{Ma})=$ 19,52; standar deviasi $(\mathrm{Sd})=2,78$; varians $\left(\mathrm{Sd}^{2}\right)$ $=7,72$; skor tertinggi $=24$; skor terendah $=13$. Dengan menggunakan teknik sturgess maka didapat banyak kelas 6 dan panjang interval 2, dan dimulai dari kelas paling bawah yaitu 13 . Dengan menggunakan ketentuan kurva normal baku maka daftar distribusi frekuensi dan gambar histogram mengenai hasil belajar yang diajar dengan menggunakan Media Pembelajaran Tipe Drill and Practice dapat dilihat pada tabel 4 . sebagai berikut.

Tabel 4. Distribusi Frekuensi Skor Hasil Belajar Yang Diajar Dengan Media Pembelajaran tipe Drill and Practice

\begin{tabular}{cccc}
\hline Kelas & Interval kelas & Fo & Fr \% \\
\hline 1 & $13-14$ & 2 & 6.45 \\
2 & $15-16$ & 1 & 3.23 \\
3 & $17-18$ & 8 & 25.81 \\
4 & $19-20$ & 9 & 29.03 \\
5 & $21-22$ & 6 & 19.35 \\
6 & $23-24$ & 5 & 16.13 \\
\hline \multicolumn{5}{r}{ Jumlah } & 31 & 100 \\
\hline
\end{tabular}

Berdasarkan tabel distribusi frekuensi diatas maka dijelaskan bahwa 11 orang siswa atau sebesar 48,56 \% skor hasil belajar di bawah skor rata-rata kelas, 15 orang atau sebesar $37,5 \%$ pada skor hasil belajar rata-rata dan 5 orang atau sebesar $16,13 \%$ diatas rata-rata.

4.2 Hasil Belajar Siswa Siswa yang diajar dengan Media Pembelajaran Tutorial

Berdasarkan tes hasil belajar yang diberikan setelah proses pemberian perlakuan, skor tertinggi pada siswa yang diajar dengan menggunakan strategi pembelajaran STAD memiliki skor rata-rata $(\mathrm{Ma})=16,57$; standar deviasi $(\mathrm{Sd})=2,69$; varians $\left(\mathrm{Sd}^{2}\right)=7,25$; skor tertinggi $=22$; skor terendah $=12$. Dengan 
menggunakan teknik sturgess maka diperoleh banyak kelas 6, panjang interval 2, dan dimulai dengan batas bawah kelas pertama yaitu 12 . Maka daftar distribusi frekuensi dan histogram mengenai hasil belajar kelompok siswa yang diajar dengan Media Pembelajaran Tipe Tutorial dapat dilihat pada tabel 5 sebagai berikut.

Tabel 5. Distribusi Frekuensi Skor Hasil Belajar Yang Diajar Dengan Media Pembelajaran tipe Tutorial

\begin{tabular}{cccc}
\hline Kelas & Interval kelas & Fo & Fr \% \\
\hline 1 & $12-13$ & 5 & 13.51 \\
2 & $14-15$ & 9 & 24.23 \\
3 & $16-17$ & 9 & 24.32 \\
4 & $18-19$ & 8 & 21.62 \\
5 & $20-21$ & 5 & 13.51 \\
6 & $22-23$ & 1 & 2.70 \\
\hline & Jumlah & 37 & 100 \\
\hline
\end{tabular}

Berdasarkan distribusi frekuensi diatas maka dijelaskan bahwa siswa atau sebesar $62,15 \%$ skor hasil belajar di bawah rata-rata kelas, dan $37,85 \%$ siswa pada skor hasil belajar di atas rata-rata.

\subsection{Pengujian Persyaratan Analisis}

Sebelum hipotesis diuji perlu dilakukan uji persyaratan analisis data. Persyaratan data yang dibutuhkan untuk menguji hipotesis adalah data yang berdistribusi normal dan homogen agar hasil penelitian dapat dipertanggung jawabkan secara penelitian jika sampel diambil secara acak (random sampling). Uji persyaratan analisis data dilakukan untuk uji normalitas, dan uji homogenitas.

\subsubsection{Uji Normalitas}

Uji normalitas ini digunakan untuk mengetahui sampel yang digunakan apakah berasal dari populasi yang berdistribusi normal atau tidak. Pengujian dilakukan dengan menggunakan uji liliefors pada kelompok sampel seperti diuraikan pada lampiran 15 karena data masih tersaji secara individu. Rangkuman hasil perhitungan normalitas dapat dilihat pada tabel 6 berikut:
Tabel 6. Ringkasan Hasil Analisis Uji Normalitas Setiap Kelompok Penelitian

\begin{tabular}{lcccc}
\hline \multicolumn{2}{c}{ Sumber Data } & Lhitung & L tabel & Kriteria \\
\hline Drill and & Pre-test & 0.1225 & 0.1591 & Normal \\
Practice & Post-Test & 0.0777 & 10.1591 & Normal \\
\hline \multirow{2}{*}{ Tutorial } & Pre-test & 0.1069 & 0.1566 & Normal \\
\hline
\end{tabular}

Hasil perhitungan uji normalitas skor hasil belajar siswa yang diajar dengan Media Pembelajaran Tipe Drill and Practice pada taraf signifikasi $\alpha=5 \%$ dengan jumlah sample $(\mathrm{dk})=31$ diperoleh $\mathrm{L}_{(0,05 ; 31)}=0,1591$ sedangkan $\mathrm{L}_{\text {hitung }}=0,0777$. Dengan demikian nyata bahwa $\mathrm{L}_{\text {(tabel) }}=0,1591>$ $\mathrm{L}_{\text {hitung }}=0,0777$, sehingga pengujian kelompok pembelajaran Tipe Drill and Practice berasal dari populasi yang berdistribusi Normal.

Hasil perhitungan uji normalitas skor hasil belajar siswa yang diajar dengan Media Pembelajaran Tipe Tutorial pada taraf signifikansi $\alpha=5 \%$ dengan jumlah sample $(\mathrm{dk})=37$ diperoleh $\mathrm{L}_{(0,05 ; 37)}=0,1457$ sedangkan L Litung $=0,1357$. Dengan demikian nyata bahwa $\mathrm{L}_{\text {(tabel) }}=0,1457>$ $L_{\text {hitung }}=0,1357$, sehingga pengujian kelompok Tipe Tutorial berasal dari populasi yang berdistribusi normal.

\subsubsection{Uji Homogenitas}

Setelah data hasil penelitian diuji normalitasnya, maka perlu dilakukan juga uji Homogenitas untuk melihat bahwa sampel penelitian adalah homogen. Uji homogenitas data menggunakan uji $\mathrm{F}$ yaitu membandingkan varians terbesar dengan varians terkeil dengan taraf signifikan 5\%. Berikut tabel hasil pengujian homogenitas data pre test dan post tes MTD antara siswa yang diajar dengan pembelajaran Tipe Drill and Practice and Tutorial.

Tabel 7. Hasil Uji Homogenitas Data Hasil Belajar

\begin{tabular}{cccc}
\hline $\begin{array}{c}\text { Sumber } \\
\text { Data }\end{array}$ & Fhitung & $\mathbf{F}_{\text {tabel }}$ & Kriteria \\
\hline Pre-test & 1.46 & 3.996 & Homogen \\
\hline Post-Test & 1.07 & 3.996 & Homogen \\
\hline
\end{tabular}




\section{Pengaruh Penggunaan Media Pembelajaran Berbasis Komputer Terhadap Hasil Belajar Menggunakan Teknik Dasar Pada Siswa Kelas X Program Keahlian Teknik Gambar Bangunan SMK Negeri 2 Medan}

Berdasarkan tabel 7 diatas, didapat bahwa nilai $\mathbf{F}_{\text {hitung }}<\mathbf{F}_{\text {tabel }}$ dan sekaligus menarik kesimpulan bahwa sampel penelitian yang diajar dengan pembelajaran Tipe Drill and Practice dengan sampel penelitian yang diajarkan dengan Tipe Tutorial adalah homogen.

\subsection{Pengujian Hipotesis}

Untuk melihat pengaruh pembelajaran Tipe Drill dalam meningkatkan hasil belajar MTD maka dilakukan uji hipotesis dengan uji $\mathrm{t}$ dua pihak. Berikut tabel ringkasan hasil perhitungan uji hipotesis uji $\mathrm{t}$ dua pihak data hasil belajar MTD:

Tabel 8. Pengujian Hipotesis Data Hasil Belajar dengan Uji t

\begin{tabular}{cccc}
\hline $\begin{array}{c}\text { Sumber } \\
\text { Data }\end{array}$ & $\mathbf{t}_{\text {hitung }}$ & $\mathbf{t}_{\text {tabel }}$ & Kriteria \\
\hline Post-Test & 4.43 & 1.671 & $\begin{array}{c}\text { Ho } \\
\text { ditolak }\end{array}$ \\
\hline
\end{tabular}

Dari tabel diatas dapat dilihat bahwa $t_{\text {hitung }}>$ $t_{\text {tabel }}$ berarti Ho ditolak.

Adapun hipotesis statistik penelitian yang diuji dalam penelitian ini adalah:

Ho $\quad: \mu \mathrm{A}_{1} \leq \mu \mathrm{A}_{2}$

Ha $: \mu \mathrm{A}_{1} \geq \mu \mathrm{A}_{2}$

Dimana:

$\mathrm{A}_{1}$ :Hasil belajar MTD kelompok siswa yang diajar dengan media pembelajaran Tipe Drill and Practice

$\mathrm{A}_{2}$ : Hasil belajar MTD kelompok siswa yang diajar dengan media pembelajaran Tipe Tutorial.

Oleh karena pada uji hipotesis harga $t_{\text {Hitung }}$ $4,43>t_{\text {Tabel }} 1,671$ maka dapat ditarik kesimpulan bahwa Ho ditolak dan sekaligus menerima Ha yaitu Rata-rata hasil belajar siswa pada pokok bahasan menggambar teknik dasar lebih baik/ tinggi dengan media pembelajaran Drill and Practice daripada media pembelajaran Tutorial di kelas X Jurusan Teknik Bangunan SMK Negeri 2 Medan.

\subsection{Pembahasan Hasil Penelitian}

Berdasarkan pengujian hipotesis pertama diperoleh bahwa media pembelajaran memberikan pengaruh yang berbeda secara signifikan terhadap hasil belajar. Selanjutnya dari hasil tersebut bahwa Media Pembelajaran Tipe Drill and Practice terbukti lebih efektif dalam meningkatkan hasil belajar siswa dibandingkan dengan Media Pembelajaran Tutorial. Disamping itu rata-rata hasil belajar siswa juga berbeda yaitu siswa yang diajar dengan Media Pembelajaran Tipe Drill and Practice memperoleh nilai tertinggi yaitu 19.52dibanding dengan siswa yang diajar dengan media pembelajaran Tutorial yaitu 16,57 .

Dalam pembelajaran Drill and Practice, pada materi pelajaran yang dipelajari dikaitkan dengan situasi dunia nyata siswa agar memudahkan mereka dalam menanggapi dan memahami pengetahuan, bahkan membuat anak didik mudah memusatkan perhatian, sehingga materi pelajaran yang akan dipelajari akan lebih berarti jika siswa mempelajari materi pelajaran yang disajikan melalui konteks kehidupan. Dalam pembelajaran ini juga siswa diberi kesempatan untuk mencari dan menemukan sendiri informasi tentang pembelajaran yang diberikan untuk menggairahkan siswa dalam menerima pelajaran, maka pengetahuam yang diperoleh siswa tidak akan cepat dilupakan tetapi dapat bertahan lama. Hal inilah yang menyebabkan hasil belajar siswa yang diajar dengan media pembelajaran Drill and Practice lebih tinggi dari hasil belajar siswa yang diajar dengan media Tutorial.

Dari penelitian ini jelas bahwa Media pembelajaran Drill and Practice memberi pengaruh yang lebih baik terhadap hasil belajar siswa dibandingkan dengan media Pembelajaran Tutorial.

\section{Kesimpulan, Implikasi dan Saran}

5.1 Kesimpulan

Berdasarkan pembahasan hasil penelitian, maka ditarik kesimpulan pada penelitian ini adalah hasil belajar MTD kelompok siswa yang diajar dengan media pembelajaran Drill lebih baik daripada hasil belajar MTD kelompok siswa yang diajar dengan media pembelajaran Tutorial, yang teruji secara statistik dengan nilai $\mathrm{t}_{\text {Hitung }} 4,43>\mathrm{t}_{\text {Tabel }} 1,671$. 


\subsection{Implikasi}

Hasil kesimpulan menyatakan siswa yang diajar menggunakan media lebih baik demi tercapainya hasil belajar yang baik pula. dan ada baiknya jika penggunaa media pembelajaran yang melibatkan siswa aktif dengan mengembangkan pola pikir dan keterampilannya lebih dioptimalkan walaupun tidak sepenuhnya harus meninggalkan jenis pembelajaran yang sudah diterapkan selama ini.

Penerapan media pembelajaran Drill menjadi salah satu bukti bahwa pembelajaran ini dapat dijadikan sebagai pilihan media pembelajaran bagi guru khususnya guru mata pelajaran MTD dalam melaksanakan proses pembelajaran tutorial. Dengan diterimanya hipotesis dalam penelitian ini, maka media pembelajaran Drill.

MTD lebih tinggi jika dibandingkan dengan siswa yang diajar dengan media pembelajaran

Penggunaan media pembelajaran yang tepat akan menciptakan suasana belajar yang juga menuntut keaktifan siswa dan guru untuk mengembangkan potensi yang ada di dalam diri siswa sehingga hasil belajar yang didapat akan lebih optimal dan siswa akan lebih bersemangat dalam belajar.

\subsection{Saran}

Berdasarkan hasil penelitian yang diperoleh, maka peneliti memberikan saran sebagai berikut:

a. Pembelajaran media berbasis komputer dapat digunakan sebagai salah satu strategi pembelajaran di dalam meningkatkan hasil belajar MTD

b. Bagi guru dan calon guru yang hendak menerapkan media pembelajaran berbasis komputer ini disarankan agar memiliki persiapan yang baik dari segi bentuk-bentuk latihan yang akan diberikan pada siswa dalam mengembangkan keterampilan siswa dan terlebih dahulu memperkenalkan metode pembelajaran ini kepada siswa, sehingga pembelajaran dapat berjalan dengan waktu yang lebih efektif.

c. Untuk penelitian lanjutan dengan variabel yang relevan hendaknya dapat memperbaiki kekurangan yang ada pada penelitian ini dengan membuat perencanaan penelitian yang lebih baik lagi untuk mendapatkan hasil yang diinginkan.

\section{Daftar Pustaka}

Arikunto, Suharsimi. 2006. Prosedur Penelitian. Jakarta: PT. Rineka Cipta

Arsyad, Azhar (2005). Media Pembelajaran. Jakarta: Rajawali Pers

Djamarah, Syaiful Bahri dan Aswan Zain. 2006. Strategi Belajar Mengajar. Jakarta: PT. Rineka Cipta

Djuharie, Otong Setiawan dan Suherli. 2005. Panduan Membuat Karya Tulis. Bandung: Yrama Widya

Drill and

Practice.(http://blog.persimpangan.com /blog/2007/08/15/drill-and practice. Kamis 23 September 2010, jam 15.58 wib)

Gagne, R.M. (Ed.). 1987. Instructional Technology: Foundations. Hillsdale: Lawrence Erlamaum Associates, Publishers

Hamalik, O. 2010. Perencanaan Pengajaran Berdasarkan Pendekatan Sistem. Bandung : Bumi Aksara

Nasution, Berbagi Pendekatan Dalam PBM, Bina Aksara. Jakarta, 1982.

Peraturan Menteri Pendidikan Nasional (Permendiknas) Republik Indonesia Nomor 22 Tahun 2009 Tentang Standar Isi Untuk Satuan Pendidikan Dasar Dan Menengah.

Purwanto. 2006. Menggambar Teknik Dasar. Direktur Pendidikan Menengah Kejuruan: DEPDIKBUD

Rusman (2013) Belajar dan Pembelajaran Berbasis Komputer: Mengembangkan Profesionalisme Guru Abad 21. Bandung. ALFABETA

Situmorang, Eni Febri. 2011. Pengaruh metode pembelajaran drill terhadap hasil belajar menggambar teknik dasar (MTD) sisw pembelajaran Drill memperoleh hasil belajar kelas X jurusan teknik bangunan di SMK N I Berastagi T.P 2010/201. Skripsi. Medan: Universitas Negeri Medan. Slameto, Belajar dan Faktor-faktor yang mempengaruhi. Rineka Cipta, Jakarta, Januari 2010

Sudjana. 2005. Metoda Statistika. Bandung: Tarsito

Surya, Mohammad, (1997), Psikologi Pembelajaran dan Pengajaran, Bandung: Bany Quari. 